NBER WORKING PAPER SERIES

A NEW SUMMARY MEASURE OF
THE EFFECTIVE TAX RATE ON INVESTMENT

Roger Gordon

Laura Kalambokidis

Joel Slemrod

Working Paper 9535

http://www.nber.org/papers/w9534

NATIONAL BUREAU OF ECONOMIC RESEARCH

1050 Massachusetts Avenue

Cambridge, MA 02138

February 2003

Presented at the CES-ifo Conference on Measuring the Effective Taxation of Capital, Venice, July 15-16, 2002. The views expressed herein are those of the authors and not necessarily those of the National Bureau of Economic Research.

C2003 by Roger Gordon, Laura Kalambokidis, and Joel Slemrod. All rights reserved. Short sections of text not to exceed two paragraphs, may be quoted without explicit permission provided that full credit including Cnotice, is given to the source. 
A New Summary Measure of the Effective Tax Rate on Investment

Roger Gordon, Laura Kalambokidis, and Joel Slemrod

NBER Working Paper No. 9535

February 2003

JEL No. H2

\begin{abstract}
The empirical literature that seeks to measure the effective tax rate on new investment offers a striking paradox. On the one hand, summary measures of the effective tax rate on new investment are normally quite high. On the other hand, the amount of revenue actually collected from taxing capital income is apparently very low.

In this paper we derive explicitly how revenue figures (under the existing system and under a hypothetical R-base tax) can be used to construct an estimate of the true effective tax rate on capital income, and how this measure and existing measures are affected by several factors, including resale of assets (churning), risk, pure profits, debt finance and arbitrage, and choice of organizational form. We conclude that our new methodology provides a very useful, but not fail-safe, approach for measuring the effective tax rate on new investment. It is much more robust than the standard measures, such as King-Fullerton marginal effective tax rates, to many commonly omitted complications in the tax law.

In trying to reconcile the high conventional measures of the effective tax rate with the low revenue collected, we conclude that the effective tax rate does seem to be much lower than existing measures suggest.
\end{abstract}

Roger Gordon

Department of Economics 0508

9500 Gilman Drive

University of California, San Diego

La Jolla, CA 92093-0508
Laura Kalambokidis

Department of Applied Economics

Room 231 Classroom Office Building

1994 Buford Avenue

University of Minnesota

St. Paul, MN 55108-1995

Joel Slemrod

Department of Economics

611 Tappan Street

University of Michigan

Ann Arbor, MI 48109-1220 


\section{A New Summary Measure of the Effective Tax Rate on Investment}

\section{Objectives}

Taxes on investment income have become high-profile candidates for reduction or repeal, given their presumed negative effects on investment and growth. Given this policy focus, economists have put significant effort toward learning how tax systems in fact affect the incentive to invest, typically by measuring the effective tax rate on new investment.

The empirical literature that seeks to measure the effective tax rate on new investment offers a striking paradox. On the one hand, summary measures of the

effective tax rate on new investment are normally quite high. ${ }^{1}$ On the other hand, the amount of revenue actually collected is apparently very low. For example, Gordon and Slemrod (1988) (hereafter GS) estimated that in 1983 the U.S. tax system collected no revenue from taxing capital income, while Gordon, Kalambokidis, and Slemrod (2001) (hereafter GKS) estimated that in 1995, the U.S. tax system collected approximately $\$ 18$ billion in revenue from corporate capital income, or just $4 \%$ of total corporate profits (equal to $\$ 441.5$ billion in 1995 according to the Economic Report of the President (1999)). ${ }^{2}$ If the taxation of capital income in fact generates little or no revenue while imposing large distortions to investment incentives, then this tax structure is hard to defend. 
On the other hand, the low revenue figures for existing taxes on capital income could be consistent with a view that the U.S. tax system does not discourage investment as severely as has been thought. The low revenue could reflect an effective tax rate on new capital investment that is much lower than has conventionally been reported in the past. This would be the case if the low revenue figures provide more revealing information about the effective tax rate because they reflect complications in the tax law ignored in standard estimates of this effective tax rate. However, revenue figures are also affected by things that do not matter for investment incentives, such as the income generated by inframarginal decisions, so it is not clear a priori how informative revenue collections are for this purpose.

While GS (1988) and GKS (2001) estimated the revenue collected from U.S. capital income taxes, they did not convert those estimates into an effective tax rate measure. Our first objective in this paper is to derive explicitly how these revenue figures can be used to estimate the effective tax rate on new investment.

We start with the simplest possible setting in section 1, with just a corporate tax and only equity finance. In this setting, we define an effective tax rate on new investment using the Hall and Jorgenson (1967) approach, as later refined by King and Fullerton (1984) (hereafter KF). In this simple setting, the resulting effective tax rate also equals one derived using the Feldstein and Summers (1979) (hereafter FS) approach that calculates an effective tax rate equal to the ratio of 
corporate tax payments (plus any personal taxes on corporate dividend and interest payments) to corporate income. Next, we show how the estimates of the revenue collected from taxing capital income, using the procedures in GKS, can be used to measure this same effective tax rate.

In section 2, we then assess all three measures when we move beyond this initial model of investment incentives. Among the complications we consider are: resale of assets (churning), risk, pure profits, debt finance, and choice of organizational form. Except in the case of choice of organizational form, where it would overestimate the effective tax rate, the GKS measure is the only one that consistently equals the desired value. That it automatically captures the effects of such complications is an important strength of this approach to measuring the effective tax rate. In the presence of these complications, the FS and KF measures as used in practice consistently overestimate the desired value for the effective tax rate, providing some help in reconciling the past evidence.

In section 3, we explore some further complications that are not dealt with appropriately by the GKS measure. The first is debt arbitrage, whereby investors in high tax brackets borrow from those in low tax brackets to buy more lightly taxed equity. The data in GS (1988) suggested that such debt arbitrage is a dominant reason why the revenue from existing taxes on capital income in the United States has been so low. With this complication introduced, we find that 
the GKS measure now underestimates the effective tax rate, while the KF and the FS measures (as used in practice) both overestimate it.

We conclude in section 4 that the GKS approach provides a very useful but not fail-safe approach for measuring the effective tax rate on new investment. This measure proves to be much more robust than the KF or the FS measures to many commonly omitted complications in the tax law. Like all backward looking measures of effective tax rates, it has one blind spot. Because it relies on ex post data on tax payments, it cannot be used to assess the effects of proposed changes in the existing law, and will not accurately reflect a recently changed law. Overall, our exploration of alternative measures of the effective tax rate on new investment leads us to conclude that, in trying to reconcile the high conventional measures of effective tax rates with the low revenue collected, that the actual effective tax rate on new investment does seem to be much lower than existing measures suggest, due to various omitted complications.

\section{Effective Tax Rate Measures: Base Case}

In this section we explore alternative means of measuring the effective tax rate on new investment in the simplest possible setting: that used in the seminal work by Hall and Jorgenson (1967). This model, based on the neoclassical theory of optimal asset accumulation, assumes perfect information, perfect competition, zero excess profits on the marginal investment, an unchanging tax law, and no 
risk. It also ignores any personal taxes on corporate-source income, abstracts from the use of debt finance, and assumes that the firm has sufficient profits to use all of the allowed credits and deductions in the earliest possible year.

Hall and Jorgenson argue that a profit-maximizing firm will purchase a new capital asset as long as the present discounted value of the stream of returns generated by the asset exceeds the cost of acquiring the asset. Such a firm will invest until the present discounted value of the returns on a marginal project just equals the acquisition cost. Normalizing the pre-tax price of the capital good to be one, we can write the single-period-equivalent maximization problem as $\operatorname{Max} f(K)-(r+d) K$.

Here $r$ is the discount rate and $d$ is the rate of depreciation of the capital goods, assumed to be exponential at rate $d$. The solution to this problem is characterized by the following condition for the marginal investment:

$$
f^{\prime}(K)-d=r \text {. }
$$

Here $f^{\prime}-d$ is the annual net return to one unit of capital. In equilibrium, it exactly equals the marginal rate of return to savings for the firm's shareholders, $r$.

Now introduce a corporation tax. The revenue generated by the investment is taxed at the corporate tax rate, denoted $u$. In addition, purchasing a capital asset entitles the owner to a stream of depreciation deductions (we ignore any 
investment tax credits). It is useful to think of the present discounted value of the tax savings generated by the depreciation deductions as a reduction in the acquisition cost of the asset. Let $z$ be the present value of depreciation deductions per dollar of acquisition cost, so that $u z$ is the present value of the tax savings resulting from the deductions allowed on one dollar of new investment. As a result, only (1-uz) dollars need to be raised from investors to finance a dollar of new investment. Similarly, only $d(1-u z)$ dollars need to be raised in each future period to cover replacement expenditures. With these adjustments, equation (1) becomes

$$
f^{\prime}(K)=\frac{(r+d)(1-u z)}{(1-u)}
$$

which can be rewritten as

$$
f^{\prime}-d=r+\frac{u(r+d)(1-z)}{1-u}
$$

Here, the second term captures the extent of any tax distortion, measuring the difference between the net return to capital and the investors' marginal rate of return to savings. It will be convenient for future purposes to denote the numerator of this term by $\Delta \equiv u(r+d)(1-z)$. One can think of $\Delta$ as measuring the extra taxes due as a result of using depreciation rather than expensing, measured as a constant figure in each year. To pay these extra taxes while still yielding a 
return of $r$ to investors, the firm needs to earn an extra $\Delta /(1-u)$ before corporate taxes.

We define the "effective tax rate," $m$, as that tax rate on net corporate income, $f^{\prime}-d$, that leads to the same equilibrium value of $f^{\prime}$, given $r$, as arises under the actual tax law. By definition, then, $m$ satisfies the following equation:

$$
\left(f^{\prime}-d\right)(1-m)=r,
$$

where the equilibrium $f^{\prime}$ is characterized by equation (2). We then find, using equations (2) and (3), that

(3) $m=\frac{\Delta}{(1-u) r+\Delta}$.

Two special cases are important. The first is expensing, under which all investment expenditures are deductible from taxable income when incurred. In this case $z$ equals one, so that $m$ equals zero regardless of the value of $u$ or $d$. The other case of interest is the pure income tax, where depreciation allowances exactly mirror the decline in value of the asset-its "economic" depreciation. Then $z$ equals $d /(r+d)$. If $d /(r+d)$ is substituted for $z$ in expression (2), then $m=$ $u$.

\subsection{King-Fullerton}

Throughout the rest of the paper, we focus on the updated version of the Hall and Jorgenson (1967) model developed by King and Fullerton (1984). Given our 
initial assumptions, their approach is equivalent to that of Hall and Jorgenson, yielding the appropriate measure of the effective tax rate on new investment in this context.

In general, King and Fullerton extended Hall and Jorgenson's cost of capital approach by taking into account personal taxes on corporate income and the range of forms of corporate finance. To do so, they estimate a marginal effective tax rate on new investment with respect to one kind of capital asset, and one kind of financing, at a time. This effective tax rate depends on the source of financing and, consequently, on the tax characteristics of the recipient of the returns. Their focus was on the resulting variation in the effective tax rate by type of investment, though in addition they take a weighted average of these effective tax rates to provide a measure of the overall effective tax rate on investment.

To obtain this weighted average effective tax rate, King-Fullerton assumed that new investment is distributed among different asset types, industries, sources of finance, and ownership characteristics in the same proportions as the current capital stock. Further assumptions arise from the inability to trace specific assets through to their ultimate owners. Specifically, the King-Fullerton study assumes that "all assets in a particular industry are financed in the same way, that all owners hold debt from the different industries in the same proportions, and that all owners hold equity from the different industries in the same proportions." ${ }^{33}$ These aspects become relevant as we add complications below to the analysis. 


\subsection{Average tax rate}

A number of studies have used observed average tax rates as an approximation of the effective marginal tax rate. As an example of this approach, Feldstein and Summers (1979) calculate an average effective tax rate equal to corporate taxes paid, plus personal taxes due on corporate dividend and interest payments, as a proportion of capital income, measured using accounting data. While the average tax rates are relatively easy to calculate, there are numerous reasons why the average rates would be poor proxies for marginal effective rates on new investment. (Fullerton (1984) lists eleven of these reasons. ${ }^{4}$ ) For example, the average effective tax rate is backward-looking: it depends on investments made by the firm over many previous periods. If the tax law has changed over time, prospective investments will face a different regime than past investments. In this case, the backward-looking measure will incorrectly characterize the impact of taxes on future investments. As another example, a firm may have little tax liability in a year when it earns high income, because earlier tax losses may have been carried forward. The result will be an average tax rate that may understate the impact of taxes on the incentive to undertake a new investment.

In the simple setting used in this section, however, the average tax rate exactly equals $m$ under specific conditions. In particular, the taxes paid in some year $t$ equal 


$$
T_{t}=u\left[f_{t}\left(K_{t}\right)-\int_{s=0}^{\infty} d_{s, t-s} I_{t-s} d s\right]
$$

where $d_{s, t-s}$ equals the depreciation deductions allowed for $s$ year old capital

originally purchased in year $t-s$, based on the tax law in force in year $t-s$. Capital purchased in year $t-s$ is denoted by $I_{t-s}$. The estimate for the effective average tax rate is then

$$
m_{F S}=\frac{T_{t}}{\left(f_{t}\left(K_{t}\right)-d K_{t}\right)},
$$

or tax liability divided by corporate income net of true depreciation.

This expression does equal the marginal tax rate, $m$, if: 1) the tax law remains fixed over time, 2) real investment has been growing at rate $r$, and 3 ) there are no business cycle effects, so that $f_{t}$ does not in fact vary with $t$. All of these pertain to the history of the tax system and investment. A fourth assumption is that there is constant returns to scale, so that $f(K)=K f^{\prime}$. From now on, for the most part we will assume that these assumptions do hold, and explore other advantages and disadvantages of using the average tax rate and other measures as an approximation of $m$. We return to the impact of relaxing some of these assumptions later.

\subsection{GKS Tax Rate}

In two earlier papers (GS (1988) and GKS (2001)), we estimated the impact on U.S. tax revenue from shifting from the current law to an R-base for both the 
corporate and the personal income tax, a tax base that excludes financial income, disallows interest deductions, and replaces depreciation, amortization, and depletion deductions with expensing for new investment. ${ }^{5}$ The difference between how much is raised under the actual tax system and the amount of revenue a hypothetical R-base tax (with the same tax rates) would raise provides an estimate of the net tax revenue collected from capital income under the current regime.

GS found that under a simulated R-base tax in 1983, the tax liability of nonfinancial corporations would increase by $\$ 22.6$ billion, and individual tax liability would fall by $\$ 15.2$ billion. On net, therefore, GS estimated that the existing income taxes collected $\$ 7.4$ billion less in tax revenue that an R-base would have, even though an R-base tax imposes no distortion to savings or investment decisions. Since this figure is a small fraction of total tax revenue, the implication of this result is that, in 1983, the U.S. tax system imposed little or no burden on the return to capital. The question we focus on is why these revenue figures can be so low, in spite of the high standard estimates of the effective tax rate on new investment.

GKS repeated this experiment using data from 1995 and found a somewhat different result. In 1995, switching to an R-base tax would have reduced corporate tax liability by $\$ 18.0$ billion and individual tax liability by $\$ 90.1$ billion, for a net revenue loss of $\$ 108.1$ billion. ${ }^{6}$ Two important reasons for the difference 
in results were the drop in nominal interest rates from 1983 to 1995, reducing the tax savings from arbitrage through the use of debt, and the much higher investment rate in 1995 compared with 1983. If 1995 had been at a more typical point in the business cycle, GKS estimated that the revenue loss from shifting to an R-base tax would have been $\$ 94.9$ billion.

In neither paper were the revenue results converted into an effective tax rate summary measure. How would we do so, at least in this simple setting?

Let $T C$ be the tax collected under the existing tax rules. Let $T R$ be the tax that would be collected under an R-based tax, holding both the return to capital and the capital stock at the existing levels, rather than at the values they would have in the equilibrium with an R-base tax. GKS focused on measuring the taxes collected under the existing law relative to an R-base tax that does not distort capital investments: $T C-T R$. This difference equals the net taxes collected on income/deductions from financial assets (dividends, interest, and capital gains) plus the effects on tax revenue from use of depreciation and amortization rather than expensing for new investment.

In general, and as calculated in GS (1988) and GKS (2001), this measure depends on the relative tax treatments of all capital, corporate and non-corporate, real and financial, under existing law compared with under an R-based tax. However, for purposes of this discussion, consider the calculation of this measure 
in an economy consisting of just a corporate sector with no personal taxes. This expression in any given year then equals:

$$
T C_{t}-T R_{t}=u\left(I_{t}-\int_{s=0}^{\infty} d_{s, t-s} I_{t-s} d s\right)
$$

Assume as before 1) an unchanging tax law and 2) real investment growing at rate $r .^{7}$ Then this expression simplifies to $u(r+d)(1-z) K=\Delta K$, where $\Delta$ is defined as earlier.

To measure $m$, we propose the following definition:

$$
m_{G K S} \equiv \frac{\left(T C_{t}-T R_{t}\right) / K}{(1-u) r+\left(T C_{t}-T R_{t}\right) / K} .
$$

In practice, as in GS(1988) and GKS(2001), $\left(T C_{t}-T R_{t}\right) / K$ can be calculated using actual U.S. tax return data, and the estimated counterfactual amount of revenue that would be collected under an R-base tax.

Note a few things about $m_{G K S}$. First, if the current tax system were equivalent to an R-base tax, so that $z$ is equal to one, $T C$ would equal $T R$, so that $m_{G K S}=0$ regardless of the value of $u$ or $r$. Second, if $T C$ was a pure income tax, so that $z=d /(r+d), m=m_{G K S}=u$.

Therefore, under the above assumptions, all three tax rates correctly measure the disincentive to invest due to taxes. All but the King-Fullerton measure require that the tax law has been unchanging in the past and that investment had been growing at a rate equal to $r$. For example, GKS recalculated $T R$ as if investment 
had been at an average, rather than a high-growth, level. That paper did not attempt to correct for changes in the tax law in the past. ${ }^{8}$ The FS measure in addition requires no business-cycle effects: Feldstein and Summers (1979) did attempt to control for business cycle effects in making use of their measure of the average tax rate.

\section{Omitted complications}

How do these three proposed measures of the effective tax rate compare with the $m$ in more complicated settings? We examine several possible complications.

\subsection{Churning}

In principle, the approach taken by Hall and Jorgenson, or later by King and Fullerton, can deal appropriately with any additional complications as long as a careful effort is made to incorporate these additional complications into the theoretical model. Since the tax law is very complicated and since the range of possible responses is also complicated, however, it is easy for tax economists to overlook issues that in practice turn out to be important - any given study cannot feasibly take account of all the detailed provisions in the law, and all the ways that firms and individuals may respond to the tax law.

The FS and GKS measures, however, can potentially take these complications into account automatically, since these complications and any behavioral 
responses to them will affect the amount of revenue collected by existing taxes. Whether the revenue effects in fact measure well the implications of any given complication in the law for marginal investment incentives, however, depends in general on the nature of the specific complication at issue.

One example of particular importance in the U.S. during the early 1980's was "churning." Churning refers to the sale of existing real capital by one firm to another firm. This sale generates taxable capital gains, which by itself discourages such a sale. However, the firm acquiring the capital can set the tax basis for the capital back up to its current market value, generating higher depreciation deductions in the future than the firm selling the asset would have been eligible for. Churning would be profitable, at least based on tax considerations, if the value of the extra depreciation deductions more than offsets the extra capital gains taxes.

This was often the case in the U.S. prior to the 1986 tax reform. Yet this type of behavioral response was ignored when many economists first tried to assess the effects of the 1981-3 tax reforms. At the time, many studies ${ }^{9}$ argued that structures faced a particularly high effective tax rate. Yet in fact, due to churning, structures were heavily subsidized under the tax law. ${ }^{10}$ What would the value of $m$ be, with churning? How are the three alternative measures affected, assuming that churning exists but that economists are not yet aware of its importance? 
Start with $m$. Consider the simple case in which all capital is churned every $c$ years. Each time capital is churned there are transactions costs equal to $\kappa$ percent of the current market value of the capital; $c$ is assumed to be the optimal rate of churning given $\kappa$. The present value of depreciation deductions on the initial investment then equals $z_{c}=\sum_{j=0}^{\infty} e^{-d c j} \int_{0}^{c} d_{s} e^{-r(s+c)} d s$, while the present value of capital gains tax liabilities, denoted by $g$, equals $\mathrm{g}=$ $\tau_{g} \sum_{j=0}^{\infty} e^{-r c j}\left(e^{-d c}-e^{-\int_{0}^{c} d_{s} d s}\right) e^{-d c(j-1)}$, where $\tau_{g}$ denotes the capital gains tax rate. Let $u z^{*}=u z_{c}-$ g. In addition, let $\kappa^{*} \equiv(r+d) \sum_{j=1}^{\infty} \kappa e^{-d c j}$ measure the constant rate of expenditure equivalent to the implied transactions costs. The first-order condition for new investment now equals $f^{\prime}-\kappa^{*}-d=r+\frac{u(r+d)\left(1-z^{*}\right)}{1-u}$. Here, as before, the last term measures the difference between the net real return to new investment and the marginal rate of return to savings.

In practice, the King-Fullerton measure ignored churning, assuming, as did Hall and Jorgenson, that firms invest permanently, so it mistakenly used $z$ to calculate $m_{K F}$. To the extent to which $z^{*}>z$, because of accelerated depreciation allowances, the measure will be in error.

What about the average tax rate measure? Under the above assumptions, if calculated correctly this measure would equal 


$$
m_{F S}=\frac{u\left[f-(r+d) z^{*} K\right]}{f-\left(d+\kappa^{*}\right) K}
$$

Under the same assumptions as before, it is easy to show that this measure equals $m$. Note, however, that the extra capital-gains taxes being incurred through churning would need to be taken into account when calculating the correct average tax rate. Instead, the standard approach has been to use an effective tax rate equal to $u+e(1-u)$. Here, $e$ represents the effective personal tax rate on dividends and capital gains, e.g. $e=v \tau_{d}+\tau_{g}(1-v)$, where $v$ is the dividend payout rate, $\tau_{d}$ is the effective personal tax rate on dividends, and $\tau_{g}$ is the effective capital gains tax rate, e.g., $\tau_{g}=.25 \tau_{d}$. When churning becomes profitable, reported depreciation deductions will jump, but the extra capital gains taxes would easily be overlooked. ${ }^{11}$ The average tax rate measure will then underestimate $m$.

What about the GKS measure? Under the behavior described above, the observed $\Delta$ would equal $u\left(I-(r+d) z^{*} K\right)=u(r+d)\left(1-z^{*}\right) K$. We then find that $m_{G K S}=m$. Therefore the GKS measure does automatically capture the effects of churning on investment incentives, even if economists are not aware of its importance. This is an illustration of an advantage of a measure based on actual tax collections. 


\subsection{Risk}

The above derivations have ignored the presence of risk. Yet corporate investments are certainly risky, and the risk premia can be very large relative to the required return on a risk-free investment. To what degree is the value of $m$, and each of the three methods for measuring $m$, affected by the presence of risk?

We address this question by considering how the previous results change if the marginal return to new investments, $\tilde{f}^{\prime}$, is now random. ${ }^{12}$ Under the tax structure described above, we would now find in equilibrium that

$$
(1-u) \tilde{f}^{\prime}=(r+d)(1-u z)+(1-u)(\rho+\tilde{\varepsilon}),
$$

where the first term on the right-hand side equals the required return, net of corporate taxes, from a risk-free investment, $\rho$ represents the risk premium that shareholders would require to hold the lottery $\tilde{f}^{\prime},{ }^{13}$ while $\tilde{\varepsilon}$ is the random return.

By definition, then, the certainty-equivalent value of the lottery $\tilde{f}^{\prime}$ equals

$\bar{f}^{\prime}-\rho \equiv f_{C E}^{\prime}$, implying that

$$
f_{C E}^{\prime}-d=r+\frac{\Delta}{1-u}
$$

To measure the effective tax rate in this setting, we want to compare the social return on this investment with the social opportunity cost, $r$. If risk has been allocated efficiently in the economy, then the risk premium on any random taxes equals the risk premium required by shareholders. The certainty-equivalent value 
of $\tilde{f}^{\prime}$, now from a social perspective, equals the same value $f_{C E}^{\prime}$ derived based on shareholder preferences. The effective tax rate, defined implicitly by the equation $\left(f_{C E}^{\prime}-d\right)(1-m)=r$ is then the same as we found without risk.

The King-Fullerton measure for this tax rate is also unaffected, as is the GKS measure. However, the average tax rate now equals

$$
m_{F S}=\frac{u\left[f_{C E}-\int_{s=0}^{\infty} d_{s, t-s} I_{t-s} d s+\rho K\right]}{f_{C E}-d K+\rho K} .
$$

The average tax rate no longer equals $m$, but instead is biased towards the statutory tax rate, $u$. Intuitively, this measure misinterprets the tax revenue collected on the risk premium as a disincentive to invest rather than as a fair premium for the reduction in risk caused by the tax levy. The larger is the risk premium, the larger is the bias.

\subsection{Pure Profits}

To this point, we have assumed that each firm has constant returns to scale. What if instead firms have a concave production function, thus earning profits on inframarginal investments in equilibrium? Would this affect the marginal effective tax rate, $m$ ? Here, the answer is an easy "no:" marginal incentives are unaffected by the rate of return earned on inframarginal projects. For the same reason, $m_{K F}$ is unaffected by having a concave production function. Nothing in 
the expression for $m_{G K S}$ is affected either. Because the revenue collected on pure profits under the existing system would also be collected by an R-base tax with the same rate structure, the presence of pure profits has no effect on the calculation of $T C_{t}-T R_{t}$ above. The $m_{G K S}$ measure is based on the revenues collected over and above the R-base tax. This is an essential and critical advantage of the GKS measure of $m$ : by construction, it depends only on those revenues that arise from marginal investments, and ignores those revenues that arise from inframarginal investments.

In contrast, the average tax rate is affected by the presence of pure profits. In particular, recall that our earlier derivation made use of the assumption that $f=f^{\prime} K$, an assumption that is valid only if the production function has constant returns to scale. Assume instead that $f=f^{\prime} K+\pi$, where $\pi$ represents the profits earned on inframarginal investments. Then the expression for the average tax rate equals

$$
m_{F S}=\frac{u\left[f^{\prime} K+\pi-\int_{s=0}^{\infty} d_{s, t-s} I_{t-s} d s\right]}{f^{\prime} K+\pi-d K}
$$

As with risk, we find that the average tax rate is biased towards the statutory rate, $u$, and the bias increases with the extent of the profits on inframarginal investment. As it does in the presence of risk, the $m_{F S}$ measure misinterprets the revenue collected from profits on inframarginal investment as evidence of a disincentive to marginal investments. 
At this point it is worth commenting briefly on another tax rate measure recently proposed by Devereux and Griffith (1998). They expand the effective tax rate concept by introducing the corporate effective average tax rate, which explicitly allows for the presence of economic rents. This tax rate is defined as the difference between the pre- and post-tax economic rent scaled by the net present value of the pre-tax income stream. This measure of the tax rate equals $m_{F S}$ under the same assumptions needed above to reconcile $m_{F S}$ and $m$ in a setting without pure profits.

While this expression does not provide an appropriate measure of the effective tax rate on marginal investments, being biased towards the statutory tax rate $u$, Devereux and Griffith argue that their tax rate measure may be of value in judging the effects of the tax law on a firm's choice between mutually exclusive investment projects that are expected to generate positive economic rents before tax. If true, the $m_{F S}$ measure would be useful in the same context.

\subsection{Debt Finance}

So far, we have assumed that corporate investments are entirely financed with equity. King and Fullerton (1984) devote considerable attention to the implications of debt finance for the incentive to invest. In their calculation of the marginal effective tax rate, they assume that: 1) there are no real costs resulting from using debt versus equity finance, but that firms can finance at most a 
fraction $b^{*}$ of their investments with debt, and 2) interest payments are tax deductible under the corporate tax, but interest income is taxable at some tax rate $\tau_{b}$ under the personal income tax.

To investigate the effects of debt finance on alternative measures of the effective tax rate, we follow these assumptions used by King and Fullerton. Furthermore, we assume for simplicity that the law allows tax depreciation allowances that are equal to economic depreciation, at rate $d$, and we ignore personal taxes on equity income as well as risk.

When a firm undertakes an additional dollar of investment, assume that it raises $b$ dollars from debt and $(1-b)$ dollars from equity. The opportunity cost equity investors face equals the return they could earn on bonds instead, so equals $r\left(1-\tau_{b}\right)$ where $\tau_{b}$ equals their personal tax rate on interest income from corporate bonds. Wealth owners are then indifferent between holding equity and debt if:

$$
(1-u)\left[f^{\prime}-r b-d\right]=(1-b) r\left(1-\tau_{b}\right)
$$

implying in equilibrium that

$$
f^{\prime}-d=\frac{r\left(1-\tau_{b}\right)(1-b)+r b(1-u)}{1-u}=r\left(1-\tau_{b}\right)+\frac{\Delta_{b}}{1-u}
$$

where $\Delta_{b}=u r\left(1-\tau_{b}\right)-\operatorname{br}\left(u-\tau_{b}\right){ }^{14}$ As long as $u>\tau_{b}$, the cost of funds is minimized if $b$ is as large as possible, implying that firms use as much debt finance as possible, so that $b=b^{*} .{ }^{15}$ In other words, the use of debt rather than equity finance generates an effective tax rate of $\tau_{b}$ rather than $u$, or a tax arbitrage 
gain of $u-\tau_{b}$. In this case the tax arbitrage arises because of the differential tax treatment of two otherwise identical ways to raise funds. This arbitrage gain is limited to $b^{*}$ times the amount of capital, so it amounts to an effective marginal subsidy to investment.

In order to summarize these complicated tax incentives in an "effective" tax rate $m$, we continue to use the following modified identity:

$$
(1-m)\left(f^{\prime}-d\right)=r\left(1-\tau_{b}\right),
$$

where $r\left(1-\tau_{b}\right)$ represents the marginal rate of return to saving. From equations (8) and (9), we find that

$$
m=\frac{\Delta_{b}}{(1-u)\left(f^{\prime}-d\right)}=\frac{\Delta_{b}}{(1-u) r\left(1-\tau_{b}\right)+\Delta_{b}} .
$$

Tax distortions now arise from both personal and corporate taxes. For example, if $b^{*}=1$, then no corporate taxes are paid. However, we still find, after a simple derivation, that $m=\tau_{b}$, due to the taxes still paid under the personal tax on the interest received by investors.

Under the above assumptions, the King-Fullerton approach calculates the correct effective tax rate, $m$. How does the average tax rate compare? To answer this question, note that total (corporate plus individual) taxes paid on the return to corporate investment equal $u(f-d K-b r K)+\tau_{b} b r K$. If we divide by the pretax return to corporate capital, $f-d K$, and simplify, we find that 


$$
m_{F S}=\frac{\Delta_{b}}{(1-u)\left(f^{\prime}-d\right)},
$$

so $m_{F S}=m$. The average tax rate calculation generates the correct effective tax rate.

Under the GKS approach, we now find that $T C_{t}-T R_{t}=u(I-d K-r b K)+\tau_{b} r b K$. Given this expression, the value for $m_{G K S}$ in equation (4) equals $m$ if and only if $I=\left(r\left(1-\tau_{b}\right)+d\right) K$, that is, when the growth rate in real investment equals the investors' discount rate, $r\left(1-\tau_{b}\right){ }^{16}$

How do the results change if instead of a constraint limiting the debt/capital ratio, the firm faces some real agency costs from having more debt that limit the size of the optimal debt/capital ratio? Assume, for example, that these agency costs as a function of the debt-capital ratio equal $a(b) .{ }^{17}$ Now optimal investment is characterized by

$$
(1-u)\left[f^{\prime}-r b-a(b)-d\right]=(1-b) r\left(1-\tau_{b}\right)
$$

so that

$$
f^{\prime}-a(b)-d=r\left(1-\tau_{b}\right)+\frac{\Delta}{1-u}
$$

The only substantive change from the situation without real costs of debt when measuring the effective tax rate on new investment is that there is an internal optimum for $b$. None of the three measures for the effective tax rate are affected by this modification. 
Note, however, that there are additional efficiency costs, $a(b)$, arising from the tax distortion favoring use of debt that are not reflected in any of these effective tax rate measures that focus strictly on investment incentives. A tax structure that generates the same effective tax disincentive, $\Delta$, without distorting the use of debt finance, instead allowing for more generous depreciation allowances, could in principle avoid this extra efficiency cost, $a(b)$.

\subsection{Choice of Organizational Form}

Another complication that is normally ignored when calculating effective tax rates is the choice of organizational form. Under U.S. tax rules, when firms have losses, they generally would prefer to face high tax rates in order to generate larger tax savings, while they would prefer low tax rates when they have profits. If some individuals face personal tax rates above the corporate tax rate, ${ }^{18}$ then a firm can structure any capital currently generating losses so that it is part of a subchapter S corporation, ${ }^{19}$ owned by investors in high tax brackets. When the capital generates profits, the firm can shift to C-corporation status, and then be taxed at the corporate tax rate.

How does this choice affect $m$, and how does it affect each of the three measures of this tax rate? Consider the following simple case. Assume that depreciation deductions are front loaded, so that projects generate tax losses during their first $s$ years, and taxable profits thereafter. The firm then chooses to 
be a pass-through entity (i.e., non-corporate or an S corporation) owned by individuals facing a tax rate above the corporate rate while it has losses, and to be a traditional $\mathrm{C}$ corporation thereafter. The project is just profitable if

$$
\int_{0}^{\infty} f^{\prime} e^{-(r+d) t} d t-\int_{0}^{\infty} u(t)\left(f^{\prime} e^{-d t}-d_{t}\right) e^{-r t} d t=1,
$$

where $u(t)$ represents the statutory marginal tax rate the firm faces in year $t$ of the project. For simplicity we assume that $u(t)$ equals the relevant non-corporate tax rate, $\tau$, during the first $s$ years of the project and the corporate rate, $u$, thereafter.

Let $u^{*}=(r+d) \int_{0}^{\infty} u(t) e^{-(r+d) t} d t$ represent the weighted average tax rate faced by the firm, and let $z^{*}=\int_{0}^{\infty} d_{t} u(t) e^{-r t} d t / u^{*}$. Then, equation (11) implies that

$$
f^{\prime}-d=r+\frac{u^{*}(r+d)\left(1-z^{*}\right)}{1-u^{*}}
$$

The expression for $m$ thus remains unchanged, except that $u^{*}$ and $z^{*}$ replace $u$ and $z$.

Applications of the King-Fullerton measure of the effective tax rate have not to date taken into account a firm's ability to choose a tax-efficient organizational form. This measure will therefore be in error to the extent that $u^{*}$ and $z^{*}$ differ from $u$ and $z$. Because these shifts in organizational form are done because they save on taxes, $m_{K F}$ will be biased upwards.

Similarly, in past work average tax rate measures have always focused on corporate tax payments and, perhaps, personal taxes due on this income when it is 
paid out as dividends or realized in the form of capital gains. Personal taxes saved at an earlier non-corporate stage of the business and shifting of income between the personal and corporate bases at a point in time have been ignored. Since the measure thus ignores the firm's tax savings during its years not subject to the corporation income tax, it also overestimates the effective tax rate.

What about the GKS tax measure? First note that, at a point in time, the firms aged $s$ or less are non-corporate (technically, they are pass-through entities), and those aged $s$ or more are corporate. Under an R-base, investment by noncorporate firms would be expensed at rate $\tau$, investment by corporate firms (of capital purchased from non-corporate firms) would be expensed at rate $u$, while the revenue generated from capital sold by a non-corporate firm would be taxed at rate $\tau$. Under the above assumptions, along with those used earlier, $T C_{t}-T R_{t}$ equals

$$
\tau I+(u-\tau) I e^{-(r+d) s}-\int_{0}^{\infty} u(t) d_{t} I e^{-r t} d t
$$

Here, the first term reflects the cost of expensing for current investment by non-corporate firms. The second term reflects the tax implications under an Rbase tax of a sale of capital by the original non-corporate firm and its purchase by a corporate firm, while the third term measures the tax cost of depreciation deductions under current law, assuming that investment has been growing at rate $r$ 
over time. This expression then equals $u^{*}(r+d)\left(1-z^{*}\right) K$, following the same derivation as before.

The resulting measure for the tax rate then equals

$$
\frac{\left(T C_{t}-T R_{t}\right)}{\left(T C_{t}-T R_{t}+r\left(1-u^{*}\right) K\right)}=\frac{\Delta^{*}}{\Delta^{*}+r\left(1-u^{*}\right)}
$$

where $\Delta^{*}=u^{*}(r+d)\left(1-z^{*}\right)$. In principle, therefore, the GKS approach provides the correct measure of the effective tax rate in this setting.

If the researcher were not aware of these changes in organizational form, as we've presumed in describing the other measures, however, then the second term in expression (13) would likely be ignored. ${ }^{20}$ In addition, $u$ rather than $u^{*}$ would presumably be used in the denominator, resulting in an overestimate of $\mathrm{m}^{21}$

\section{Other Complications, Part 2}

So far, we have compared the three approaches for measuring the effective tax rate with a baseline measure in a variety of settings. In principle, the KingFullerton approach can deal appropriately with any complication, assuming that the model is extended to address it. However, in practice, it is infeasible to address more than a small number of issues. In particular, applications to date have ignored churning and the choice of organizational form, in each case resulting in an overestimate of the effective tax rate. 
One advantage of the other two measures is that they have the potential to capture the effects of any and all complications without the researcher having specific knowledge of these complications, since the data on tax payments will automatically reflect these complications. This was to some degree true for the Feldstein-Summers measure with respect to churning. However, the FS measure does not deal appropriately with risk, pure profits, or the choice of organizational form, in each case resulting in a substantial overestimate of the investment disincentive due to taxes.

The GKS measure does, however, handle all of these complications well. Even without explicit knowledge of the researcher, it would handle appropriately all but the choice of organizational form, where it would overestimate the investment disincentive.

The results so far (summarized in Table 1) thus suggest that the low tax revenue observed in GS (1988) and in GKS (2001) indeed implies that the actual effective tax rate is low, and therefore there is little or no resulting distortion to investment incentives. In fact, due to the implications of the choice of organizational form, the revenue collected and the resulting distortion may have both been overestimated. The apparent inconsistency between the high effective tax rates reported in the past literature and the low revenue yield is then explained simply by errors in the calculations of the effective tax rate in the previous literature. 
However, this conclusion is not robust. In this section, we consider other complications that are not dealt with appropriately under the GKS measure, thus leading us to a more ambiguous set of conclusions. To begin with, we consider the effects of portfolio arbitrage by individual investors, in particular the tendency of investors in high tax brackets to borrow from those in low tax brackets, saving substantially on the deduction of the interest payments and then investing the funds in more lightly-taxed assets. GS (1988) found that this form of debt arbitrage was responsible for a substantial loss of tax revenue, and was an important reason why in 1983 existing U.S. taxes on capital income collected little or no revenue.

\subsection{Debt Arbitrage}

In section 2.4, we considered the implications of corporate borrowing, but in a setting in which all investors faced the same personal tax rate, $\tau$. Consider what happens in a more general setting in which investor $i$ faces a personal tax rate of $\tau_{i}$, with rates varying by investor. Each individual can now invest in either bonds or equity. If we continue with the simplifying assumption used by King and Fullerton that there is no risk, for each individual one or the other asset will offer a higher after-tax rate of return. In the absence of any restrictions on short holdings and negative tax liabilities, each individual would want to have an unlimited short position in the lower-yielding asset and an unlimited long position 
in the higher-yielding asset. Thus, some further consideration must be added to the analysis to explain the existence of equilibrium portfolios. In what follows, we assume that individuals can buy positive amounts of either asset without restriction, but can borrow ${ }^{22}$ only up to some proportion $\beta$ of their personal savings; that is, if individual $i$ has savings of $S_{i}$, then she can borrow at most $\mathrm{B}_{\mathrm{i}}=\beta S_{i}{ }^{23}$ Let $e$ represent the rate of return on equity, net of any corporate taxes. Then individual $i$ will borrow to buy equity only if $e>r\left(1-\tau_{i}\right)-$ if she borrows, she will borrow up to the allowed limit of $\beta S_{i}$. If $e<r\left(1-\tau_{i}\right)$, the individual will instead put all her wealth in bonds. Only the marginal investor for whom $e=r\left(1-\tau_{i}\right)$ will be indifferent between debt and equity. Let the tax rate of this marginal investor be denoted by $\tau^{*}$.

The marginal after-tax rate of return to savings differs by investor, and clienteles for debt and equity form. For those with $e \leq r\left(1-\tau_{i}\right)$, extra savings are simply invested in bonds, so that the marginal return equals $r\left(1-\tau_{i}\right)$. In contrast, for investors facing $e>r\left(1-\tau_{i}\right)$, each extra dollar of savings enables the individual to borrow an additional $\beta$ dollars as well. The net return to savings for those that borrow, deduct interest payments on their debt, and invest in equity is then $e+\beta\left(e-r\left(1-\tau_{i}\right)\right)=r\left(1-\tau^{*}\right)+\beta r\left(\tau_{i}-\tau^{*}\right)$. 
Figure 1 graphs this rate of return to an additional dollar of savings, as a function of the individual's tax rate, $\tau_{i}$. Here, we see that savings incentives are a V-shaped function of the tax rate, with a minimum rate of return to savings for the marginal investor for whom $e=r\left(1-\tau^{*}\right)$. Denote the after-tax, or net, return to savings of individual $i$ by $r_{i}^{n}$.

What happens to the equilibrium value of $f^{\prime}$ ? By definition, the net rate of return to equity is denoted by $e$. Therefore $\left(f^{\prime}-d-b r\right)(1-u)=(1-b) e$. Since $e=r\left(1-\tau^{*}\right)$, equation (8) continues to hold, now with $\Delta_{b}=u r\left(1-\tau^{*}\right)-b r\left(u-\tau^{*}\right)$. This focus on the "marginal" investor is the typical strategy used for handling heterogeneous investors under the King-Fullerton approach. Equation (8), with $\tau=\tau^{*}$, then describes $m_{K F}$ in this setting.

In contrast to the setting with a uniform personal tax rate at rate $\tau^{*}$, however, now virtually all investors earn an after-tax rate of return to savings that is higher than the opportunity cost of funds, $r\left(1-\tau^{*}\right)$, used in deriving the equilibrium value of $f^{\prime}$. Therefore, for virtually all investors the $m_{K F}$ measure overestimates the tax distortion between the marginal product of capital and the investor's after-tax marginal rate of return to savings.

More formally, given the equilibrium value of $f^{\prime}$, we can calculate the effective tax rate faced by any given investor using the equation

$$
\left(f^{\prime}-d\right)\left(1-m_{i}\right)=r_{i}^{n},
$$


implying that

$$
m_{i}=\frac{\Delta_{b}}{(1-u)\left(f^{\prime}-d\right)}-\frac{r_{i}^{n}-r\left(1-\tau^{*}\right)}{f^{\prime}-d} .
$$

Since $r_{i}^{n} \geq r\left(1-\tau^{*}\right)$, we see that $m_{i} \leq m_{K F}$, implying that the King-Fullerton approach overestimates the effective tax rates faced by all investors except those subject to a personal tax rate of $\tau^{*}$.

Given that effective tax rates vary by investor, what is the right measure of the overall effective tax rate? Or, in other words, what measure best summarizes the distortion caused by the tax system? As tax rates become more heterogeneous, holding the mean tax rate fixed, the excess burden grows, since the excess burden grows approximately with the square of the tax rate. In particular, the excess burden generated by the distorted incentives faced by any individual $i$ equals approximately $.5 m_{i} d S_{i}$. If the behavioral response has constant elasticity, then $d S_{i} / S_{i} \approx \alpha m_{i}$ for some $\alpha$, implying an excess burden of $.5 \alpha m_{i}^{2} S_{i}$ for individual $i$ and an overall excess burden of $\sum_{i} .5 \alpha m_{i}^{2} S_{i}$.

The measure of the effective tax rate that best summarizes the total excess burden should be such that this overall excess burden, $\sum_{i} .5 \alpha m_{i}^{2} S_{i}$, equals $.5 \alpha m^{2} \sum_{i} S_{i}$.

We then infer that 


$$
m=\left(\frac{\sum_{i} m_{i}^{2} S_{i}}{\sum_{i} S_{i}}\right)^{.5}
$$

so that $m$ equals the weighted root-mean squared average of the $m_{i}$.

Easier to calculate, but without a clear conceptual underpinning, is the savings-weighted-mean tax distortion, $\bar{m}=\sum_{i} m_{i} S_{i} / \sum_{i} S_{i}$. As applied to the current U.S. economy, the savings-weighted-mean rate is probably quite low, because a large fraction of wealth is held either directly by those in the highest tax brackets or by pension funds and other financial intermediaries that are effectively in a zero tax bracket, giving high weight to the lowest values of $m_{i}$. However, $\bar{m}<m$ : relative to $\bar{m}, m$ gives much more weight to individuals facing high tax rates. It is still the case, however, that $m<m_{K F}$.

In order to understand better the values of the other two tax measures, consider how they compare with $\bar{m}$. Simple algebra reveals that

$$
\bar{m}=\frac{\Delta_{b}}{(1-u)\left(f^{\prime}-d\right)}-\frac{r^{n}-r\left(1-\tau^{*}\right)}{f^{\prime}-d},
$$

where $r^{n}$ is the weighted average return to savings across tax brackets. This becomes our reference point.

Consider in comparison an average tax rate measure. Corporate tax payments still equal $u\left(f^{\prime}-r b-d\right) K$. In addition, personal taxes are owed on the resulting interest income. Now calculate the average tax rate measure that results if one 
takes these personal taxes into account but ignores the tax deductions that arise because of borrowing, which is our reading of past practice. The weighted average personal tax rate on interest income, denoted by $\tau^{a}$, equals

$\tau^{a}=\int_{0}^{\tau^{*}} \tau_{i} S_{i} \varphi\left(\tau_{i}\right) d \tau_{i} / \int_{0}^{\tau^{*}} S_{i} \varphi\left(\tau_{i}\right) d \tau_{i}$, where $\phi$ measures the number of investors in each tax bracket. ${ }^{24}$ Then taxes on interest income per unit of total capital equal $r b \tau^{a}$. The average effective tax rate generated using this approach, after some simplifying algebra, equals

$$
m_{F S}=\frac{\Delta_{b}}{(1-u)\left(f^{\prime}-d\right)}-b \frac{r\left(1-\tau^{a}\right)-r\left(1-\tau^{*}\right)}{f^{\prime}-d} .
$$

Comparing equations (10) and (10c), we find that $m_{K F}>m_{F S}$, since necessarily $\tau^{a}<\tau^{*}$. In equilibrium only those with low marginal tax rates hold debt, so averaging those tax rates will certainly be lower than the tax rate that makes investors indifferent between holding debt and equity.

How does $m_{F S}$ compare to the measure shown in equation (10b)? Answering this question requires a comparison of $r^{n}$ and $r\left(1-\tau^{a}\right)$. Here, $r^{n}$ is a weighted average of all of the net returns to savings seen in Figure 1, while $r\left(1-\tau^{a}\right)$ is a weighted average across only those tax rates to the left of the bottom of the V. As the figure is drawn, the two could be quite close. For purposes of discussion, if $r\left(1-\tau^{a}\right) \approx r^{n}$, then $m_{F S}>\bar{m}$. How it compares to $m$ is harder to judge. 
What about the GKS approach? If, as we do in GS and GKS, one includes in the measure of $T R_{s}$ the revenue effects of eliminating interest deductions as well as interest income, the resulting estimate for the effective tax rate equals

$$
m_{G K S}=\frac{u(I-d K-r b K)+\int_{0}^{\tau^{*}} r \tau_{i} S_{i} \varphi d \tau_{i}-\int_{\tau^{*}}^{1} \beta r \tau_{i} S_{i} \varphi d \tau_{i}}{(1-u)\left(f^{\prime}-d\right) K}
$$

To see this, recall that in a closed economy all equity and corporate debt is owned by domestic investors. In addition, ignore other financial assets, such as non-corporate businesses or government debt. Given these assumptions, net holdings of debt by domestic individuals must equal net corporate borrowing. It follows that

$$
m_{G K S}=\frac{\Delta_{b}}{(1-u)\left(f^{\prime}-d\right)}-\frac{r^{n}-r\left(1-\tau^{*}\right)}{(1-u)\left(f^{\prime}-d\right)} .
$$

Comparing equations (10b) and (10d), we find that $\bar{m}>m_{G K S}$. Since $m>\bar{m}$, we can conclude that $m_{G K S}<m<m_{K F}$. At least in this context, we thus find that the GKS approach underestimates the impact of taxes on the incentive to invest, while the KF approach overestimates it. Which provides a better approximation would require a close examination of the data. 


\subsection{Personal Taxes on Equity Income}

So far, we have for the most part ignored any personal taxes on dividends or capital gains income from equity holdings. In doing so, we ignored a variety of issues that have been raised in the past literature.

Consider first the size of the distortion generated by the current tax treatment of equity. To make sense of this, the literature has first been forced to come up with a reason why dividends are paid, since dividends are at a clear tax disadvantage relative to share repurchases. One approach, followed for example by Auerbach (1979) and Bradford (1981), assumes that shares cannot be repurchased. In their model, a tax on dividends lowers the value of existing equity, but does not affect investment incentives, at least for investments financed with retained earnings. An alternative explanation for dividends was developed by Bernheim (1991), who argues that dividends and share repurchases are used jointly by firms to signal their profitability. There is some optimal cost for such a signal, inducing firms to use some weighted average of dividends and share repurchase that generate this optimal cost. Any taxes on dividends change the mixture of dividends and share repurchase used, while having no real effect on the firm's investment incentives. ${ }^{25}$ While both theories say that taxes on dividends should be ignored, all three methods examined in this paper view these tax payments as equivalent to other taxes on income from investment, and to that extent overestimate the effective tax rate. In each case, an explicit modification in 
the derivation of the measure would be needed to be consistent with these theories.

Assessing the effects of taxes on realized capital gains raises a different set of complications. As discussed in Stiglitz (1983), under U.S. tax law individuals have an incentive to realize capital losses immediately, and to postpone realizing capital gains at least until they qualify for the lower rate imposed on "long term" gains, and perhaps holding these capital gains until death when they become tax free. In addition, any taxes on capital gains result in risk-sharing with the government, so that the certainty-equivalent tax payment can be much below the expected tax payment. Taking into account both of these effects, Constantinides (1983) found that the existing tax treatment of capital gains likely makes equity investments more attractive than in their absence, implying a negative effective tax rate. None of these complications have been taken into account seriously in the public finance literature, and in particular none of the three measures studied makes any attempt to deal with them, presuming in each case that the expected tax rate is appropriate. ${ }^{26}$ As a result, each of them will overestimate the effective tax rate on capital gains.

\section{Conclusions}

The past literature investigating taxes on capital income provides a striking contrast between papers that report very high reported effective tax rates on new 
investment - with the accompanying distortions--and others that report very low additional tax revenue compared with a tax that does not at all distort savings and investment decisions. If taken at face value, these facts together make a compelling case that the current tax treatment of capital income needs reform.

Alternatively, the low reported revenue from existing taxes may imply that past measures of effective tax rates may be biased upwards. The most widely used past measure, developed initially by Hall and Jorgenson (1967) and refined by King and Fullerton (1984), uses a theoretical model to derive an effective tax rate, taking into account what are presumed to be the most important aspects of the tax law and the most important types of behavioral responses. To be feasible, however, in practice many aspects of the law and of behavior have to be ignored. A user must hope that the effects of these omitted issues are of second-order importance. One interpretation of low reported tax revenue is that these omitted issues together are not in fact of second-order importance, and instead together imply that the actual effective tax rate on new investment is very low.

The other approach, used for example by Feldstein and Summers (1979), is to calculate the average tax rate, equal to corporate tax payments plus personal taxes due on corporate income, relative to pretax corporate income. Any aspect of the tax law and any aspect of behavior will automatically affect observed tax payments. The hope is that the resulting average tax rate provides an appropriate summary of the implications of these many different complications for the 
incentive to invest, including those omitted in practice from the King-Fullerton type measure of the effective tax rate.

In this paper, we first follow the King-Fullerton framework to define an effective tax rate that correctly measures the impact of taxes on the incentive to invest in any given setting. We then adopt this tax rate as a standard to which we compare the King-Fullerton and Feldstein-Summers measures, as they have been used in practice, as well as a third measure developed in this paper.

The new effective tax rate measure is based on the approach developed initially in GS (1988) for estimating the net revenue collected by taxing capital income. Net tax revenue is estimated by calculating how much tax revenue would change if new investment could be expensed, rather than depreciated, and if all financial income were free of tax. As shown in the Meade Committee Report (1978), such an "R-Base" tax leaves savings and investment decisions undistorted. In section 1, we proposed a new effective tax rate measure based on this methodology for calculating the net revenue collected from capital income. Ideally, this measure automatically captures the effects of any and all complications in the tax law and any and all types of behavioral responses, but is not biased by the tax revenue that arises from inframarginal investments or risk premia imbedded in the average return to capital.

We find in the simplest setting all three measures are identical and provide a correct estimate of the effective tax rate on new investment. The average tax rate, 
however, will be strongly biased towards the statutory tax rate once risk and pure profits are taken into account, making it an unreliable approach to measuring the effective tax rate. In several situations, explored in section 2, the GKS approach does in fact automatically capture the effects of complications that in practice have been omitted from the reported effective tax rates derived using the KingFullerton approach. In each of these cases, the King-Fullerton measures overestimate the effective tax rate. Table 1 presents a summary comparing the effective tax rate with those derived using each of the three approaches.

Viewed naively, these results from section 2 suggest that the difference between the high effective tax rates reported in the past and the low revenue yield may well be due primarily to biases in past measures of the effective tax rate, and that the GKS measure is the best approach of the three for measuring the impact of taxes on investment incentives. However, a notable qualification is that the GKS tax measure relies on ex post data on tax payments under the law, so it cannot be used to assess the effects of proposed changes in the existing law and will not accurately reflect a recently changed law. Even with an unchanging tax law, the GKS approach does not deal appropriately with a set of other complications. In particular, it underestimates the disincentive due to the effects of debt arbitrage, while it overestimates the disincentive due to the current tax treatment of dividends and capital gains. 
Because of its superiority on a number of important dimensions, we propose that the GKS measure of the effective tax rate on new investment be added to the pantheon of existing measures. We recognize, though, that any measure of the effective tax rate-including the GKS measure - is imperfect and must therefore be used with caution. At a minimum, any differences in the estimates of the effective tax rates across measures should be investigated further, as these differences may indicate complications ignored by the investigator. 


\section{References}

Auerbach, Alan J. 1979. "Wealth Maximization and the Cost of Capital," Quarterly Journal of Economics 93, pp. 433-46.

Bernheim, B. Douglas. 1991. "Tax Policy and the Dividend Puzzle," Rand Journal of Economics 22, pp. 455-76.

Bradford, David F. 1981. "The Incidence and Allocation Effects of a Tax on Corporate Distribution," Journal of Public Economics 15, pp. 1-22.

Bulow, Jeremy and Lawrence H. Summers. 1984. "The Taxation of Risky Assets," Journal of Political Economy 92, pp. 20-39.

Constantinides, George M. 1983. “Capital Market Equilibrium with Personal Tax." Econometrica 51, pp. 611-36.

Devereux, Michael P. and Rachel Griffith. 1998. "The Taxation of Discrete Investment Choices.” Mimeo. Institute for Fiscal Studies, London. 
Feldstein, Martin and Lawrence Summers. 1979. "Inflation and the Taxation of Capital Income in the Corporate Sector.” National Tax Journal. 32(4), pp.445-471.

Fullerton, Don. 1984. “Which Effective Tax Rate?” National Tax Journal. 37(1), pp. 23-41.

Fullerton, Don and Yolanda Henderson. 1984. "Incentive Effects of Taxes on Income from Capital: Alternative Policies in the 1980's." In The Legacy of Reagonomics: Prospects for Long Term Growth, eds. Charles R. Hulten and Isabel V. Sawhill. Washington: Urban Institute Press.

Gordon, Roger and James R. Hines, Jr. 2002. "International Taxation," National Bureau of Economic Research Working Paper No. 8854.

Gordon, Roger and Young Lee. 2001. "Do Taxes Affect Corporate Debt Policy? Evidence from U.S. Corporate Tax Return Data.” Journal of Public Economics 82, pp. 195-224.

Gordon, Roger, James R. Hines, and Lawrence H. Summers. 1987. "Notes on the Tax Treatment of Structures." In The Effects of Taxation on Capital 
Accumulation, ed. Martin Feldstein. Chicago: University of Chicago Press, pp. 223-54.

Gordon, Roger and Joel Slemrod. 1983. "A General Equilibrium Study of Subsidies to Municipal Expenditures.” Journal of Finance, 38(2), pp. 585-594.

Gordon, Roger and Joel Slemrod. 1988. "Do We Collect Any Revenue from Taxing Capital Income?" In Tax Policy and the Economy, Vol. 2, ed. Lawrence Summers. Cambridge: MIT Press, pp. 89-130.

Gordon, Roger, Laura Kalambokidis, and Joel Slemrod. 2001. "Do We Now Collect Any Revenue from Taxing Capital Income?" Conference paper presented at the International Seminar in Public Economics conference, Berkeley, CA, December 7-8, 2001.

Gordon, Roger H. and John D. Wilson. 1989. "Measuring the Efficiency Cost of Taxing Risky Capital Income,” American Economic Review 79, pp. 427-39. 
Grubert, Harry and Joel Slemrod. 1998. "The Effect of Taxes on Investment and Income Shifting to Puerto Rico." Review of Economics and Statistics 80(3), pp. 365-373.

Hall, Robert, and Dale Jorgenson. 1967. “Tax Policy and Investment Behavior." The American Economic Review. 57(3), pp. 391-414.

King, Mervyn and Don Fullerton, eds. 1984. The Taxation of Income from Capital: A Comparative Study of the United States, the United Kingdom, Sweden, and West Germany. Chicago: University of Chicago Press.

Meade Committee. 1978. The Structure and Reform of Direct Taxation. Boston: Allen \& Unwin.

Miller, Merton H. and Franco Modigliani. 1961. "Dividend Policy, Growth, and the Valuation of Shares." Journal of Business 34, pp. 411-33.

Slemrod, Joel. 2001. "A General Model of the Behavioral Response to Taxation." International Tax and Public Finance, 8(2), pp. 119-128. 
Stiglitz, Joseph. 1983. "Some Aspects of the Taxation of Capital Gains," Journal of Public Economics 21, pp. 257-94.

Stiglitz, Joseph. 1985. "The General Theory of Tax Avoidance." National Tax Journal. 38(3), pp. pp. 325-338.

United States Council of Economic Advisers. 1999. Economic Report of the President, 1999. Washington, DC: U.S. Government Printing Office.

United States Department of the Treasury. 1984. Tax Reform for Fairness, Simplicity, and Economic Growth: The Treasury Department Report to the President. Washington: U.S. Department of the Treasury. 


\section{FIGURE 1}

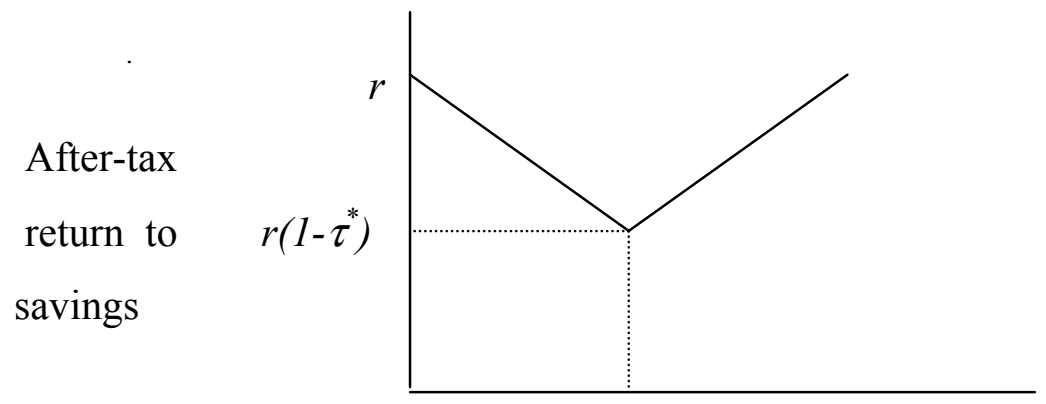

Marginal personal tax rate 
Table 1

\begin{tabular}{|c|c|c|c|}
\hline & King-Fullerton & Feldstein-Summers & $\begin{array}{l}\text { Gordon- } \\
\text { Kalambokidis- } \\
\text { Slemrod } \\
\end{array}$ \\
\hline $\begin{array}{l}\text { Algebraic } \\
\text { formula } \\
\text { (general) }\end{array}$ & $\begin{array}{l}m_{K F}= \\
\frac{u(r+d)(1-z)}{(1-u)\left(f^{\prime}-d\right)}\end{array}$ & $\begin{array}{l}m_{F S}= \\
\frac{u\left[f_{t}\left(K_{t}\right)-\int_{s=0}^{\infty} d_{s, t-s} I_{t-s} d s\right]}{f_{t}\left(K_{t}\right)-d K_{t}}\end{array}$ & $\begin{array}{l}m_{G K S}= \\
\frac{T C_{t}-T R_{t}}{K r(1-u)+T C_{t}-T R_{t}}\end{array}$ \\
\hline $\begin{array}{l}\text { Tax law } \\
\text { allows } \\
\text { expensing }\end{array}$ & $m_{K F}=0$ & $m_{F S}=0$ & $m_{G K S}=0$ \\
\hline $\begin{array}{l}\text { Tax law } \\
\text { allows } \\
\text { economic } \\
\text { deprec. }\end{array}$ & $m_{K F}=u$ & $m_{F S}=u$ & $m_{G K S}=u$ \\
\hline Churning & $m_{K F}>m$ & $m_{F S}<m$ & $m_{G K S}=m$ \\
\hline Risk & unchanged & $\begin{array}{l}m_{F S}= \\
\frac{u\left[f_{C E}-\int_{s=0}^{\infty} d_{s, t-s} I_{t-s} d s+\rho K\right]}{f_{C E}-d K+\rho K}\end{array}$ & unchanged \\
\hline Pure profits & unchanged & $m_{F S}=\frac{u\left[f^{\prime} K+\pi-\int_{s=0}^{\infty} d_{s, t-s} I_{t-s} d s\right.}{f^{\prime} K+\pi-d K}$ & unchanged \\
\hline $\begin{array}{l}\text { Debt } \\
\text { finance }\end{array}$ & $\begin{array}{l}\text { With economic deprec.: } \\
m_{K F}=1-\frac{r\left(1-\tau_{b}\right)}{\left(f^{\prime}-d\right)} \\
=m\end{array}$ & $m_{F S}=m$ & $m_{G K S}=m$ \\
\hline $\begin{array}{l}\text { Choice of } \\
\text { organiz. } \\
\text { form }\end{array}$ & $m_{K F}>m$ & $m_{F S}>m$ & $m_{G K S}>m$ \\
\hline $\begin{array}{l}\text { Key to } \\
\text { notation }\end{array}$ & $\begin{array}{l}m=\text { effective tax rate } \\
r=\text { discount rate, } \\
d=\text { depreciation rate } \\
u=\text { corporate tax rate } \\
z=\text { present value of } \\
\text { depreciation deductions } \\
\tau_{b}=\text { personal income tax rate } \\
\text { on interest income }\end{array}$ & $\begin{array}{l}f_{s}\left(K_{s}\right)=\text { return to capital in year } s \\
K_{s}=\text { stock of capital in place in year } s \\
d_{s, t-s}=\text { depreciation deductions allowed for } \\
\text { investments made at time } t-s \\
I_{t-s}=\text { investment at time } t-s \\
\rho=\text { risk premium } \\
f_{C E}=\text { certainty equivalent value of the return to } \\
\text { capital } \\
\pi \text {-profits from inframarginal investments }\end{array}$ & $\begin{array}{l}T C_{s}=\text { tax revenue collected } \\
\text { under current law in year } \mathrm{s} \\
T R_{s}=\text { tax revenue collected } \\
\text { under R-base tax in year } \mathrm{s}\end{array}$ \\
\hline
\end{tabular}


Figure 1 caption:

After-tax Rate of Return to Saving as a Function of the Marginal Personal Tax

Rate

Table 1 caption:

Summary measures under different complications 
${ }^{1}$ Feldstein and Summers (1979) found the effective total tax rate on corporate capital income to be about 66 percent in 1977. King and Fullerton (1984) found overall effective total tax rates on capital income to be about 37 percent in 1980 . ${ }^{2}$ These revenue estimates equal the difference between revenue collected under the current law and revenue collected if income and deductions from financial investments were instead tax exempt and if depreciation deductions on real investments were replaced by expensing. ${ }^{3}$ King and Fullerton (1984), p. 235.

${ }^{4}$ Among the items on Fullerton's list that are dealt with in this paper are the existence of pure profits, the presence of risk, and the use of debt finance. Fullerton (1984), pp. 28-29.

${ }^{5}$ An R-base tax imposes a zero marginal tax rate on new investment and saving, and is described in detail in Meade Committee (1978).

${ }^{6}$ This revenue loss figure reflects changes in the tax treatment of all forms of savings and investment, not just investment in corporate capital.

${ }^{7}$ In contrast to the FS measure, business cycle effects and possible economies/diseconomies to scale do not affect the estimated revenue figures here. 
${ }^{8}$ To do so would require recalculating what taxes would have been paid in the current year if the current law had in fact been in effect for the indefinite past. The key correction needed is for depreciation deductions, since investment purchased in the past continues to be depreciated based on the rules existing at the date of the investment rather than under current provisions. It would in principle be feasible to estimate by how much depreciation deductions would have differed if all capital were being depreciated under the current law, though such a calculation has not been attempted to date.

${ }^{9}$ See, for example, Fullerton and Henderson (1984) and United States Treasury (1984).

${ }^{10}$ For further discussion, see Gordon, Hines, and Summers (1987). Note that the firm making use of the structure need not change when ownership changes hands. The initial owner may simply become a renter.

${ }^{11}$ In fact, since reported corporate profits fall, presumed capital gains tax payments fall as well.

${ }^{12}$ Bulow and Summers (1984) argued that results could differ with random depreciation rather than random return. Gordon and Wilson (1989) explored this issue more carefully, and found that the key issue is the timing of new investment in the future. If new investment tends to be large when the economy is doing well, then individuals pay the resulting taxes on this investment when they can 
best afford it, so that risk in fact reduces the effective tax rate. The model discussed in the text has nonstochastic investment rates, so this complication does not arise.

${ }^{13}$ For example, in a two-period setting, this risk premium would equal $\operatorname{cov}\left(f^{\prime}, U^{\prime}\right) / E U^{\prime}$.

${ }^{14}$ This expression equals the foregone income each year from not having been allowed to expense the original investment, $\operatorname{ur}\left(1-\tau_{b}\right)$, minus the tax savings arising from the use of debt finance.

${ }^{15}$ The difference in the riskiness of equity returns depending on the debt-equity ratio is immaterial according to the logic of Miller and Modigliani (1961).

${ }^{16}$ Based on the data in the Economic Report of the President, the average annual real growth rate in nonresidential fixed investment between 1959 and 1997 was $4.6 \%$, which seems quite close to commonly presumed discount rates.

${ }^{17}$ The assumption that $a$ is a function only of $b$ is not an innocuous one. Alternatively, consider the implications if we were to write $a(b, K)$. Then the firstorder condition for $\mathrm{K}$ would have an additional term that is the partial derivative of $a$ with respect to $K$. In the extreme case in which the non-tax cost of debt was unrelated to $K$-implying that $a(b, K)=a^{\prime}(b) / K$ — the tax benefits of using debt are entirely inframarginal and do not reduce the effective tax rate on new investment. We do not pursue this case because its empirical implication of sharply declining 
debt-capital ratios with the size of the firm—is not observed. Nevertheless, as elaborated on in Slemrod (2001), the nature of the non-tax costs of a tax preference, and in particular whether they are inframarginal or not, is crucial to understanding the relationship between the foregone revenue and the impact on the marginal incentives.

${ }^{18}$ This is more likely if the firm has tax losses, since the effective corporate tax rate on losses is close to zero, due to limits on corporate tax loss carry-forwards, but there is immediate deductibility of losses under the personal tax.

${ }^{19}$ A Subchapter S firm is legally a corporation, but is taxed as a pass-through entity.

${ }^{20} \mathrm{GS}$ (1988) and GKS (2001) in fact did ignore this term.

${ }^{21}$ In particular, relative to $m$, the resulting measure would add $(\tau-u)(r+d)$ to the numerator, and $(\tau-u)(r+d)+r\left(u^{*}-u\right)$ to the denominator. The result is an upward bias as long as the $m$ is below $(m-u)(r+d) /\left[(m-u)(r+d)+r\left(u^{*}-u\right)\right]>.5$.

${ }^{22}$ Borrowing implies negative holdings of debt. We do not allow negative holdings (short sales) of equity.

${ }^{23}$ A special case, of course, has no borrowing, in which case $\beta=0$.

${ }^{24}$ Both Feldstein and Summers (1979) and King and Fullerton (1984) used a weighted average of the marginal tax rates on gross interest income calculated 
with the TAXSIM model of the National Bureau of Economic Research. With this method, the weights are the shares of interest income received by taxpayers facing different tax rates. (See Feldstein and Summers (1979), p. 454, and King and Fullerton (1984), p. 201.)

${ }^{25}$ If the tax becomes either too high or too low, however, then the firm's signal will be at a corner solution - either all dividends or all share repurchase--so it will involve costs different from the firm's optimal costs for a signal. With higher costs of a signal, the firm's expenses are higher, and investment could fall. ${ }^{26}$ The KF and FS measures also in practice ignore capital losses, and focus solely on the effective tax rate on capital gains. 